\title{
Rosemary Lloyd, Théodore de Banville: la corde raide entre forme fixe et vers libres
}

Ida Merello

\section{(2) OpenEdition}

1 Journals

\section{Edizione digitale}

URL: http://journals.openedition.org/studifrancesi/33487

DOI: 10.4000/studifrancesi.33487

ISSN: 2421-5856

\section{Editore}

Rosenberg \& Sellier

\section{Edizione cartacea}

Data di pubblicazione: 1 décembre 2005

Paginazione: 667

ISSN: 0039-2944

\section{Notizia bibliografica digitale}

Ida Merello, «Rosemary Lloyd, Théodore de Banville: la corde raide entre forme fixe et vers libres», Studi Francesi [Online], 147 (XLX | III) | 2005, online dal 30 novembre 2015, consultato il 18 avril 2021. URL: http://journals.openedition.org/studifrancesi/33487 ; DOI: https://doi.org/10.4000/studifrancesi. 33487

Questo documento è stato generato automaticamente il 18 avril 2021.

\section{(c) (i) $\Theta$}

Studi Francesi è distribuita con Licenza Creative Commons Attribuzione - Non commerciale - Non opere derivate 4.0 Internazionale. 


\title{
Rosemary Lloyd, Théodore de Banville: la corde raide entre forme fixe et vers libres
}

\author{
Ida Merello
}

\section{NOTIZIA}

ROSEMARY LLOYD, Théodore de Banville: la corde raide entre forme fixe et vers libres, «Revue d'histoire littéraire de la France, Paris, P.U.F., juill.-sept. 2004, 104e année, $n^{\circ} 3$, pp. 655-672.

L'A. vede in Banville uno degli antesignani del verso libero, concordando con Clive Scott, che lo considera a sua volta un promotore, per quanto indiretto. In effetti Banville mostra apprezzamento per il vers libre classique, ossia il vers blanc, soprattutto di Molière e di La Fontaine, ma diffida i contemporanei dall'imitazione. Tuttavia fu grande sperimentatore, mostrando una grande libertà prosodica e soprattutto l'attenzione all'effetto sorpresa; in questo rinnovato interesse per la forma fissa l'A. vede proprio l'inizio di quel gusto della sperimentazione che prelude al verso libero moderno. 